Published by the UFS

http://journals.ufs.ac.za/index.php/trp

(c) Creative Commons With Attribution (CC-BY)

How to cite: Myers, G. Walz, J. \& Jumbe, A. 2020. Trends in urban planning climate adaptation

and resilience in Zanzibar, Tanzania. Town and Regional Planning, no.77, pp. 57-70.

\section{Trends in urban planning, climate adaptation and resilience in Zanzibar, Tanzania}

\author{
Garth Myers, Jonathan Walz \& Aboud Jumbe
}

DOI: http://dx.doi.org/10.18820/2415-0495/trp77i1.5

Peer reviewed and revised November 2020

Published December 2020

*The authors declared no conflict of interest for this title or article

\begin{abstract}
Over recent decades, there has been substantial change in Zanzibar, due to, among others, global climate change impacts. The semi-autonomous polity faces challenges to foster resilient urban communities and planning for mitigation and adaptation to climate change, not least because of its island nature and rapid urbanization. This article addresses urban and environmental planning measures from 2010 to 2020 aimed at confronting the impacts of climate change and working toward resilience and adaptation in urban Zanzibar. The study was conducted between June and August 2020, and primarily involved a combination of desktop studies, online discussions, and virtual meetings with key actors in the land, climate, and disaster risk policy and governance aspects in Zanzibar. The review provides information on the current responses to policy, legal and institutional setup in terms of the key issues related to land use, climate and disaster risk reduction in Zanzibar. Thematic analysis was used to connect land-use planning, climate adaptation, and disaster risk reduction documentation of the situational assessment, determination and respective recommendations concerning land use and climate adaptation. It is argued that planning for climate change requires greater social will, financial investment, and the conversion of science to policy than currently exists in Zanzibar. Dynamic individual and governmental efforts and select community engagement are likely insufficient to produce resilience, as large-scale donor-funded climate adaptation interventions are largely top-down in orientation and often miss out on local community-oriented climate solutions. Smaller NGOs are more practical for understanding and addressing community-oriented priorities to support climateresilient initiatives and enhance local livelihood priorities and participation against climate impacts, including natural disasters and everyday degradation. The article concludes with policy recommendations both specific to Zanzibar and relevant across the region.
\end{abstract}

Keywords: Adaptation, global climate change, policy interventions, urban planning, Zanzibar

\section{TENDENSE IN STEDELIKE BEPLANNING, \\ KLIMAATSAANPASSING EN VEERKRAGTIGHEID IN ZANZIBAR, TANZANIË}

Die afgelope dekades het daar aansienlike verandering in Zanzibar plaasgevind, onder meer weens die wêreldwye impak op klimaatsverandering. Die semi-outonome regering staar uitdagings in die gesig om veerkragtige stedelike gemeenskappe te bevorder en te beplan vir die versagting en aanpassing by klimaatsverandering, nie die minste nie, te wyte aan die aard van die eiland en vinnige verstedeliking. Hierdie artikel handel oor stads- en omgewingsbeplanningsmaatreëls van 2010 tot 2020 wat daarop gemik is om die gevolge van klimaatsverandering die hoof te bied en te werk aan veerkragtigheid en aanpassing in stedelike Zanzibar. Tematiese ontledings is gebruik om landgebruiksbeplanning, klimaatsaanpassing en ramprisikoverminderingsdokumentasie van die situasiebepaling, vasstelling en onderskeie aanbevelings rakende grondgebruik en klimaatsaanpassing te verbind. Die argument is dat die beplanning vir klimaatsverandering groter maatskaplike wil, finansiële investering en die omskakeling van wetenskap tot beleid vereis as wat tans in Zanzibar bestaan. Dinamiese individuele en regeringspogings en uitgesoekte gemeenskapsbetrokkenheid is waarskynlik onvoldoende om veerkragtigheid te bewerkstellig, aangesien grootskaalse skenkers gefinansierde klimaatsaanpassingsintervensies grotendeels van bo na onder in oriëntering is en die plaaslike gemeenskapsgerigte klimaatoplossings mis. Kleiner NRO's is meer prakties om gemeenskapsgerigte prioriteite te verstaan en aan te spreek om klimaatsbestande inisiatiewe te ondersteun en plaaslike lewensbestaanprioriteite en deelname teen klimaatsinvloede te verbeter, insluitend natuurrampe en alledaagse agteruitgang. Die artikel gee beleidsaanbevelings, spesifiek

Dr. Garth A. Myers, PhD. Paul E. Rather Distinguished Professor of Urban International Studies and Director, Center for Urban and Global Studies, 300 Summit Street, Trinity College, Hartford, Connecticut, USA 06106. Phone: 1-860-297-4273, email: <garth.myers@trincoll.edu>, ORCID: https:// orcid.org/0000-0001-5370-2389.

Dr. Jonathan R. Walz, PhD. Associate Professor, Climate and Environment, School for International Training-Graduate Institute, Brattleboro, Vermont, USA and Zanzibar, Tanzania. P.O. Box 3040 Vuga, Zanzibar, Tanzania. Phone: 255-754313545, email: <jwalz.us@gmail.com>, ORCID: https://orcid.org/000-0003-4647-8504.

Dr. Aboud S. Jumbe, PhD. Environmental Scientist, Department of Environment, Government of Zanzibar, P.O. Box 628, Zanzibar, Tanzania. Tel: 255-778900448, email: <aboud.jumbe@gmail.com>, ORCID: https://orcid.org/0000-0002-8563-3071. 
vir Zanzibar en ook relevant in die hele streek.

Sleutelwoorde: Aanpassing, beleidsintervensies, stedelike beplanning, wêreldwye klimaatsverandering, Zanzibar

\section{MEKHOA EA MERALO EA LITOROPO, HO IKAMAHANYA LE MAEMO A LEHOLIMO LE BOTSITSO TOROPONG EA ZANZIBAR, TANZANIA}

Lilemong tse mashome tsa ho feta, ho bile le phetoho e kholo Zanzibar, ka lebaka la hara tse ling, litlamorao tsa phetoho ea maemo a leholimo. Leano le ikemetseng la boipuso le tobane le liphephetso ho matlafatsa sechaba sa litoropo se ikemiselitseng le ho rala bakeng sa ho fokotsa le ho ikamahanya le phetoho ea maemo a leholimo, haholoholo ka lebaka la hore kesehlekehleke seo litoropo tsa sona li holang ka potlako e kholo. Sengoliloeng sena se bua ka mehato ea moralo oa litoropo le tikoloho ho tloha 2010 ho isa 2020 e reretsoeng ho tobana le litlamorao tsa phetoho ea maemo a leholimo le ho sebeletsa ho ba le botsitso le ho ikamahanya le maemo a leholimo litoropong tsa Zanzibar. Phuputso e entsoe pakeng tsa Phuptjane le Phato 2020, mme e kenyelletsa haholo-holo motswako oa lithuto tsa desktop, lipuisano le likopano tsa inthanete le batšehetsi ba ka sehloohong molemong oa maano a mobu, maemo a leholimo, maemo a leholimo le likotsi tsa koluoa 'mooho le puso toropong ea Zanzibar. Tlhatlhobo ena e fana ka tlhaiso-leseling mabapi le likarabo tsa hajoale ho maano, melao le thophiso ea setheo ho latela lintlha tsa bohlokoa tse amanang le ts'ebeliso ea mobu, maemo a leholimo le likotsi tsa likoluoa Zanzibar. Tlhatlhobo ea lihloho e sebelisitsoe ho hokahanya moralo oa ts'ebeliso ea mobu, ho ikamahanya le maemo a leholimo, le litokomane tsa phokotso ea likotsi tsa likoluoa, boikemisetso le likhothaletso tse fapaneng mabapi le ts'ebeliso ea mobu le phetoho ea maemo a leholimo. Ho hlahisoa hore ho rala phetoho ea maemo a leholimo ho hloka thato e kholo ea sechaba, tsetelo ea lichelete le phetolelo ea mahlale ho maano, 'me sena se lokela ho etsahala maemoong a holimo ho feta a teng Zanzibar. Boiteko bo matla ba motho ka mong le ba mmuso le ho khetha tšebelisano 'moho le sechaba li kanna tsa se lekane ho hlahisa mamello, joalo ka ha liphallelo tse kholo tse tšehelitsoeng ke bafani li le maemong a holimo haholo' me hangata li fetoa ke tharollo ea maemo a leholimo a lehae. Mekhatlo e ikemetseng e sebetsa haholo bakeng sa kutloisiso le ho sebetsana le lintho tse tlang pele sechabeng tse tšehetsang mehato ea ho loants'a maemo a hlobaetsang a leholimo le ho ntlafatsa merero ea boipheliso ea lehae le ho nka karolo khahlanong le litlamorao tsa maemo a leholimo, ho kenyeletsoa likoluoa tsa thaho le ho senyeha hoa letsatsi le letsatsi. Sengoloa se phetheloa ka likhothaletso tsa maano a ikhethileng ho Zanzibar le ho sebetsa ho potoloha le naha.

\section{INTRODUCTION}

The years 1990 to 2020 brought tremendous political, economic, social and environmental changes to Zanzibar. Since 1990, the semi-autonomous polity within the United Republic of Tanzania has experienced the re-introduction of both a multiparty political system and a capitalist economy built primarily around tourism (Keshodkar, 2013: 55-86; Gössling, 2002: 540-541; Killian, 2008: 100-109). These transformations have coincided with both the substantial migration of mainland Tanzanians to the islands and significant influences from global social forces, including the near-constant presence of many thousands of European and North American tourists amid the global revitalization of Islam (Keshodkar, 2013: 111-138; Larsen, 2005: 145-157). This change has both produced significant environmental change and coincided with the acceleration of palpable impacts from global climate change (Myers, 2002: 149; Myers, 2016: 83-11).

Change creates an extraordinarily challenging landscape in which to foster resilient urban communities and planning for mitigation and adaptation to accelerating climate change impacts. Zanzibar has rapidly urbanized throughout the period since its independence (December 1963), revolution (January 1964), and union with Tanganyika to form Tanzania (April 1964) (Muhajir, 2020: 9; Myers, 1993: 21; Myers, 2016: 83). This small archipelago (with its main islands of Unguja - often called Zanzibar - where the city of Zanzibar is located, and Pemba) has a population of roughly 1.8 million
(Muhajir, 2020: 15). The urban area also known as Zanzibar serves as the capital, with an estimated metropolitan population of just over 700,000 as of 2020 (Muhajir, 2020: 26). This figure combines the Zanzibar Urban District, with slightly over 200,000 people (including the small 'Stone Town' historic district, now home to less than 10,000 ) and the rapidly urbanizing West $A$ and West $B$ districts with 500,000 residents (Myers, 2020: 82). The urban area's population is now 14 times the size it was (less than 50,000) in 1963 (Myers, 1993: 347; Muhajir, 2020: 28). This rapid pace of urbanization comes with a sprawling geographical footprint, since most of the residential development consists of single-family homes, compounding sustainability challenges in spheres such as solid waste management, air and water pollution, soil and beach erosion, and environmental health (Paula, 2016: 91-93).

From 2010 to 2020 , environmental planning measures sought to confront climate change impacts and ensure resilience and adaptation in urban Zanzibar. However, such efforts became entangled in a power dynamic between land-use authorities and the city's residents. The land tenure system in Zanzibar is guided under the Land Tenure Act - the principal land legislation that was promulgated in 1992. The Commission for Lands (COLA) is mandated to implement the Zanzibar land policy, subsequent land management related acts, set standards and norms for land ownership and rights, including dispute settlements, as well as integrate land-use planning, conservation and management activities (Revolutionary Government of Zanzibar, 2017: 1). The Land Tenure Act has since undergone numerous amendments in response to the growing friction between landuse authorities and local communities over the land ownership-development nexus. As a result, the Act has been implemented under conditions of growing challenges that result from accelerated population growth, urban sprawl, non-inclusive land-use 
planning approaches, and social inequity. This compounding effect of social and environmental pressures has precipitated endless land-use conflicts and induced numerous impediments to address the impacts of climate change. Such precipitous outcomes have often negatively affected the sustainability of the country's development plan.

This article examines the government-led, poverty-reduction and strategic growth development (popularly known by its Swahili acronym as "MKUZA") planning efforts working toward resilience, mitigation, and adaptation in urban Zanzibar. Given the size of Unguja Island (Zanzibar island) and the intertwined economies of urban Zanzibar and communities throughout the island - for example, the city's landfill is miles outside the Urban-West Region, and all tourist arrivals depend on the city's infrastructure regardless of their eventual destination on Unguja -, the entire island is included in the analysis, with some reference to the urbanizing contexts of lesspopulated but nearby Pemba island (Myers, 2016: 98). It is argued that planning for climate change requires greater social will and a sustained financial investment than currently exist in Zanzibar. Dynamic individual and governmental efforts and select community engagement are likely insufficient to produce resilience, unless there is a cohesive strategy to ensure social equity and inclusion aimed at the islands' local community-oriented climate solutions that enhance local livelihood priorities against climate impacts.

The narrative begins by framing climate change and urban planning in Africa, including the continent's contributions and vulnerabilities. Zanzibar is targeted as a case study, because it is an island exposed to intensifying cyclonic episodes from the outer western Indian Ocean region, fluctuating precipitation, flooding, rising seas, and changed air and sea surface temperatures. These documented changes have impacted on its people and their livelihoods, its urban infrastructure, and its natural resources. Next, Zanzibar' primary climate adaptation strategies and action plans are reviewed, including their policy and financing interventions for sustainability. It is noted that Zanzibar's planning and implementation have not sufficiently addressed climate change impacts, due in part to the island's rapid population growth and a climate-land nexus scenario that is overwhelming natural resources accessibility. It is argued that there is an urgent need to strengthen institutional capacity for planning, implementation, and inter-sectoral collaboration, in order to reduce the threats and impacts of climate-linked natural disasters. While Zanzibar has had remarkable productivity in terms of new climate and environmental change plans and institutions for urban and island-wide management, evidence suggests that these have not been sufficient to mitigate impacts and ensure resilience in the archipelago. Large scale, but particularly NGO-based financing and mainstreaming of climate adaptation is urgently needed. Probabilistic assessments of climate risks impacts should employ technology and data sets to address and reduce vulnerabilities. The conclusion suggests new and updated strategies to tackle the ongoing challenges of urban planning and climate change resilience and adaptation in Zanzibar and the wider region.

\section{METHODOLOGY}

The study was conducted between June and August 2020, and primarily involved a combination of desktop studies, online discussions, and virtual meetings with key actors in the land, climate, and disaster risk policy and governance aspects in Zanzibar. Specifically, the study entailed the desktop review of relevant policies, strategies, legislation, documentation, and grey literature related to climate, disaster risk and land-use planning in Zanzibar. The key focus was to address progress, opportunities, and challenges that Zanzibar faced in the midst of the
Government of Zanzibar's efforts to address climate change adaptation, disaster risk preparedness and land-use planning - under resource limitations. The review of secondary data, including peer-reviewed and academic sources, publications from official development assistance programmes relevant to climate, disaster risk and development interventions in Zanzibar were key in the development of this study.

Secondary data was collected via an online search or personal contacts with relevant agencies, and selective online and virtual meetings on climate, disaster risk and land nexus with purposively selected stakeholders in Zanzibar. The onset of the COVID-19 pandemic severely limited the targeted attempt to address cross-sectoral institutional consultations, in-person meetings, and focused discussions with stakeholders. Alternatively, we reviewed key Government policy and legal documents, publications from development partners such as the United Nations, World Bank, United Kingdom Aid, and other support initiatives carried out by NGOs such as The Hague Institute for Global Justice, The International Institute for Environment and Development (IIED), and others. Important cases from natural disaster episodes in Zanzibar were sourced via global news platforms such as the BBC and Al Jazeera, while certain secondary data on disaster loss was cited from the Relief web platform.

The review provided information of current responses to policy, legal and institutional setup on the key issues related to land use, climate and disaster risk reduction in Zanzibar. Thematic analysis was used to connect land-use planning, climate adaptation and disaster risk reduction documentation of the situational assessment, determination and respective recommendations concerning land use and climate adaptation. 


\section{GLOBAL CLIMATE CHANGE AND URBAN PLANNING IN AFRICA}

Global climate change constitutes perhaps the most urgent arena of development planning and environmental policy for Africa's urban areas. Yet the knowledge bases and policy frameworks for dealing with climate change are often skewed. Addaney and Cobbinah (2019: 7) note that "Africa's contribution to global climate change is comparably negligible [yet] it remains the most affected region". Climate change is also under-researched in both rural and urban studies in Africa. The study by Addaney and Cobbinah (2019) is the first comprehensive survey for the region's cities, and no such survey exists for rural Africa (see also Simon \& Leck, 2014; Du Toit, Cilliers, Dallimer, Goddard, Guenat \& Cornelius, 2018).

Moreover, African actors and agents have had less of a voice in developing and implementing global climate change adaptation and mitigation policy frameworks. Policies imposed on Africa from the global North often 'undermine' local actions to combat climate change, and instead "privileging international actors and financial markets" (Ernstson \& Swyngedouw, 2019: 15; Silver, 2019: 133). There is a great diversity to impacts, outcomes and planning capacities on the continent. Addaney and Cobbinah's (2019:

4) edited volume forges past the potentially debilitating realisation that such diversity might engender, while acknowledging that "adaptation to ... climatic variations has become a daunting task for governments, city authorities and residents". Their research showed the diversity within Ghana alone. Zanzibar manifests both the outsized reliance on global North actors and institutions common in Africa and the diversity across Tanzania, comparable to the Ghana case studied by Addaney and Cobbinah (2019: 4).

Addaney (2019: 482) noted that, in Africa, the urban vulnerabilities "are well-documented [but] less attention has been paid to how the city government plans to adapt to climate change and enhance the resilience of the local population." Urban Africans are not always hopelessly incapable of developing adaptation and resilience strategies. African governments and NGOs play important roles, for example, in the Sustainable Urban Development Network out of United Nations Habitat in Nairobi, which launched its Cities and Climate Change Initiative in 2008 (Myers, 2020: 173). This study contributes to building this understanding of the actions and capacities of local governments.

Water is one of the most complicated sources of risk in the context of global climate change in African environments, especially in cities. Half of all Africa's cities with over 750,000 people are within 50 miles of the coast, and many others (including some of the region's largest urban areas such as Kinshasa, Khartoum, and Brazzaville) are predominantly located in low-lying riverine settings (UN-Habitat, 2014: 45). Coastal cities or near-coastal cities are likewise also often on river mouths, estuaries, or deltas. UN-Habitat (2014: 45) considers 14 big cities (those with over one million people), six intermediate cities $(500,000$ to a million residents), and 37 small cities (100,000-500,000 people) in Africa to be at risk, due to rising sea levels. A great many cities in Africa face other significant flood risks, which are often most severe in poor, informal settlements. Even in cities at relatively high average elevations, poorer areas and informal settlements are typically at lower elevations in zones subject to seasonal flooding. Khartoum, Dar es Salaam, Mogadishu, Maputo, Dakar and many other major urban areas have experienced severe flooding over the past few years alone (Myers, 2016: 35; Kebede \& Nicholls, 2011: 16-22; Aljazeeranews, 2019; Reliefweb, 2018). Vulnerabilities from climate change do not stop with sea-level risk and flooding. As a low-lying coastal city, Zanzibar has had very comparable experiences to other cities on the continent examined in these other studies.

Zanzibar is selected for this study because it represents the uniqueness of a sub-national "semi-autonomous" island-state planning dilemma on climate adaptation and showcases the socio-economic complexities of coastal climate-related vulnerabilities facing the United Republic of Tanzania. The study area is thus an excellent setting for comparison with the regional trends discussed earlier. Many of the risks and challenges are exceedingly comparable.

\section{PLANNING IN ZANZIBAR AND THE CLIMATE CHANGE CONTEXT}

\subsection{Climate change vulnerabilities in Zanzibar}

Zanzibar, like many other coastal cities in the western Indian Ocean region, is experiencing higher than average physical growth and development rates. This is causing urban, economic, environmental and future development constraints, which increase coastal vulnerability (Celliers \& Ntombela, 2015: 337). Land-use planning in Zanzibar has existed since 1923, but the first island-wide planning was achieved in 1995, with the formulation of the national land-use plan (Muhajir, 2020: 40). However, lack of effective coordination, low levels of enforcement and monitoring, and poor communications continue to remain as prevalent challenges (Revolutionary Government of Zanzibar, 2014: 2). This article highlights land planning-related issues of unplanned settlement, unsustainable development, and inadequate capacity for environmental management from a climate vulnerability perspective, in the context of the recently approved national spatial development strategy (Revolutionary Government of Zanzibar, 2014: 2).

As a small island state, Zanzibar has become increasingly more prone to climate risk, as well as vulnerable to natural disasters, including floods, 
droughts and tropical storms.

Zanzibar is particularly vulnerable, because it has an extensive low-lying coastline, with the total land area of 2,654 square kilometres. The majority of the archipelago's 1.8 million people live just under an average of 5 metres above sea-level (Muhajir, 2020: 45).

=Rising sea water levels, saltwater intrusion, land degradation, erratic rainfalls, and urban sprawl have imposed a huge burden on the socio-economic drivers and livelihoods of Zanzibar's vulnerable communities, perhaps even more so than elsewhere on Tanzania's coastline (Yanda, Bryceson, Mwevura \& Mung'ong'o, 2019: 3-13). The recent record of direct damage to infrastructure, crops, and settlements has contributed to the increased deficits in terms of development goals. These damages have also imposed new challenges on the development commitments intended to pull the population out of poverty and into the middleincome level of development.

\subsection{Planning responses and adaptation}

\subsubsection{Climate adaptation study}

The Zanzibar Government developed its first climate adaptation study in 2010, under the bilateral Sustainable Management of Lands and Environment Support Program financed by Finland. This report, 'Preparation of an Adaptation Program of Action for Zanzibar', served as the local equivalent to the National Adaptation Program of Action Requirement of the United Nations Framework Convention on Climate Change. The Report

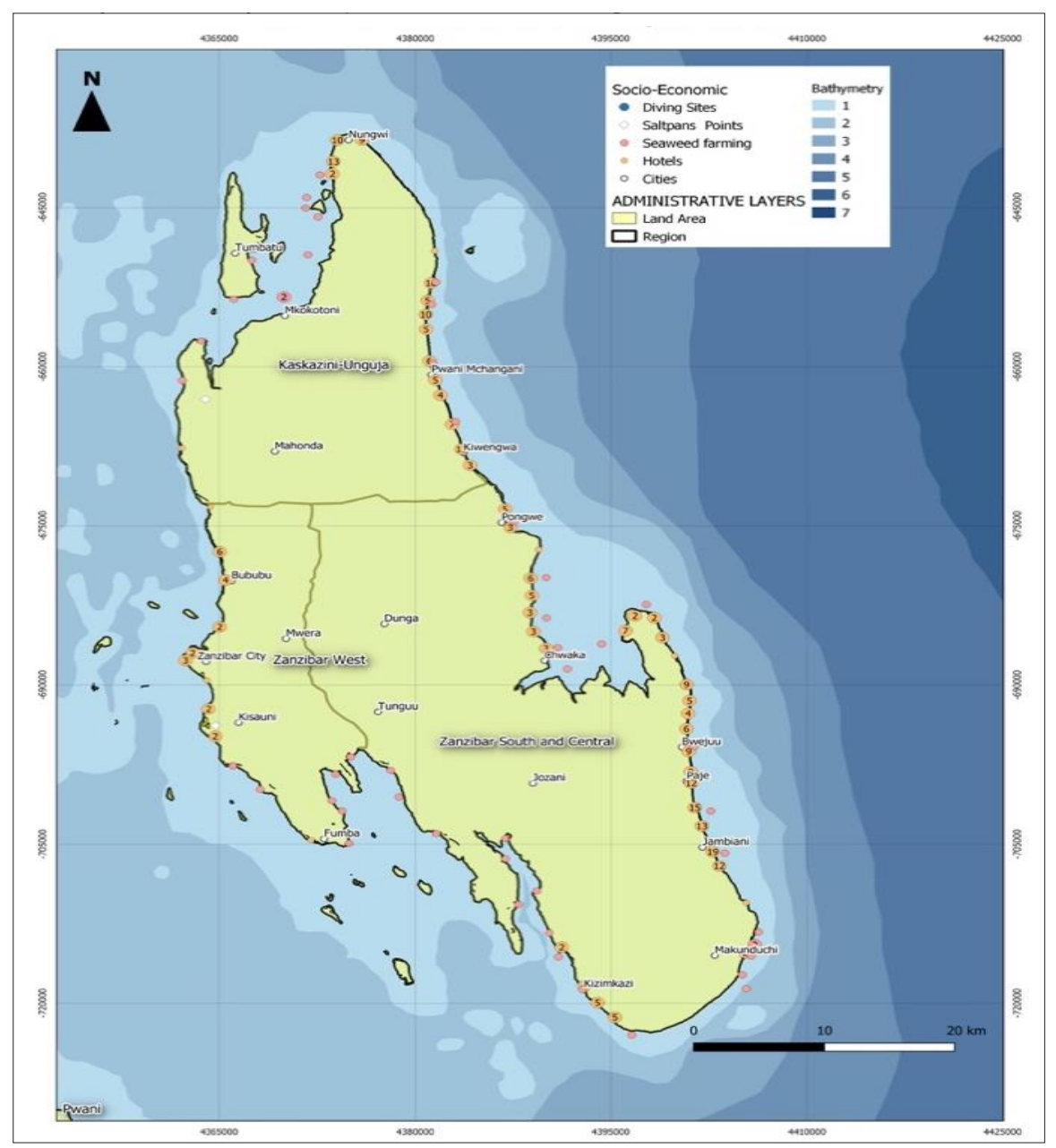

Figure 1: The main island of Zanzibar. The spots indicate areas that are currently directly affected by the impacts of climate change

Source: Zanzibar, Department of Environment, 2019: 7 identified the climate priorities that were of great concern to the local communities. These included extreme weather events; sea level rise and beach erosion; decreasing access to freshwater quality; saltwater intrusion; food insecurity; re-emergence of threats on human health; loss of forestry and biodiversity, and decreasing fisheries catch (Moller, 2010: 13).

The direct links between land-use planning and climate-induced impacts identified in the initial national adaptation study focused on coastal zone management, the tourism sector, groundwater conservation, sustainable practices in agriculture, and the protection of existing forest cover.

\subsubsection{Merging science and policy for climate adaptation}

However, addressing these measures required a systematic climate change response and adaptation strategy. Without cross-sectoral mobilization of the socio-economic pillars of growth and development, it would always be difficult for the islands to cope with the widening scope of impacts of climate change that had already begun to affect its strategic development planning. The 2012 study on Economic impacts of climate change in Zanzibar, or EICC (Watkiss, Pye, Hendriksen, MacLean, Bonjean, Jiddawi, Shaghude, Sheikh \& Khamis, 2012: 1) revealed extreme climate variability projections for the next 50 years from 2012 to 2062 , with continued patterns of erratic rainfall, rising temperatures, rough sea waves, and strong winds. Since a large proportion of Zanzibar's GDP was associated with climate-sensitive activities, people's livelihoods (the majority of which include agriculture, fishing, or tourism) were greatly dependent on these changing weather and climate dynamics that exacerbated patterns such as floods, droughts, and storms (Revolutionary Government of Zanzibar, 2012: 1).

The EICC study identified key sectoral priorities to be integrated into the development paradigm. 


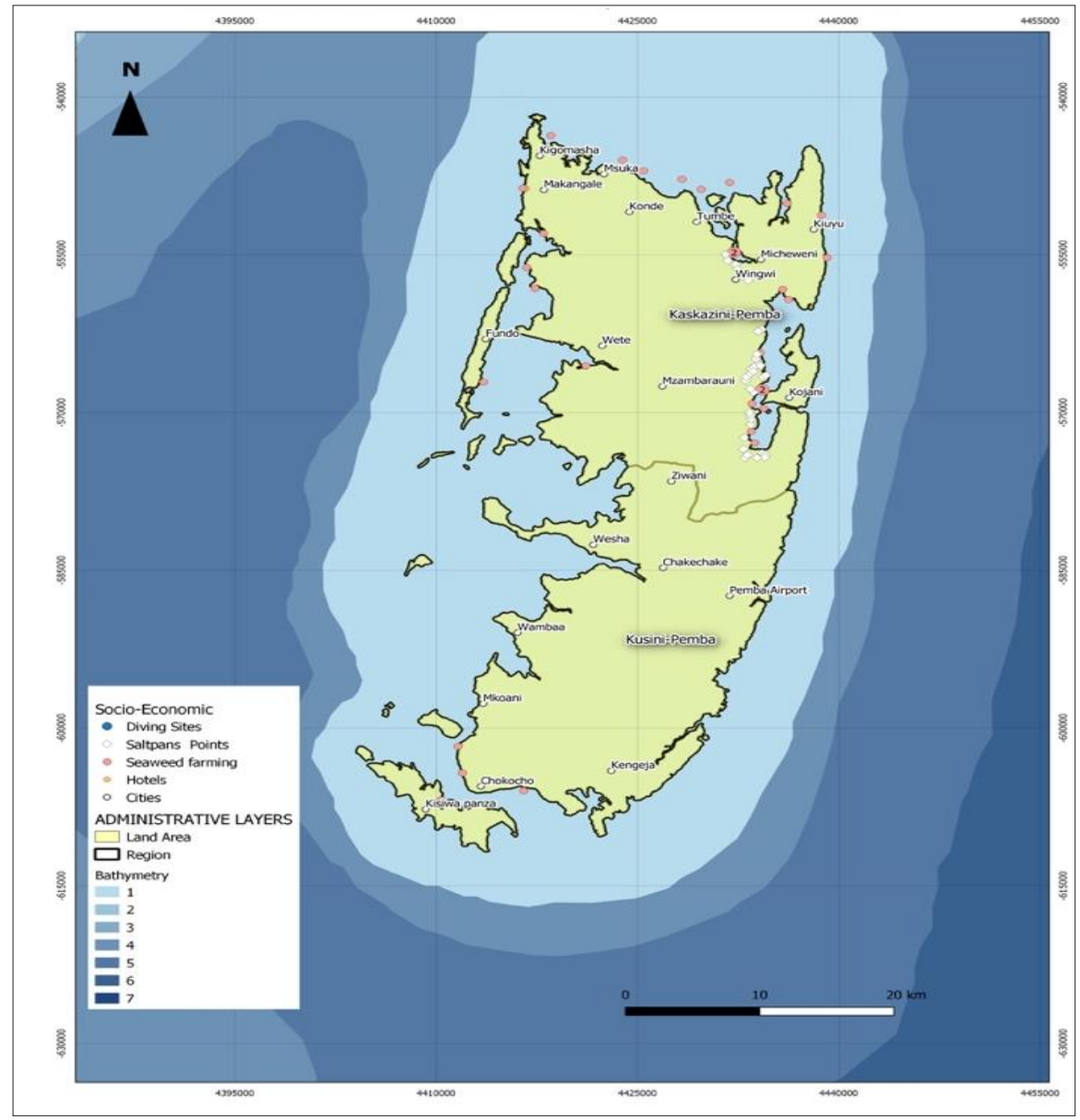

Figure 2: The map of the sister island of Pemba showing sites affected by the impacts of climate change

Source: Department of Environment, Zanzibar, 2019: 7

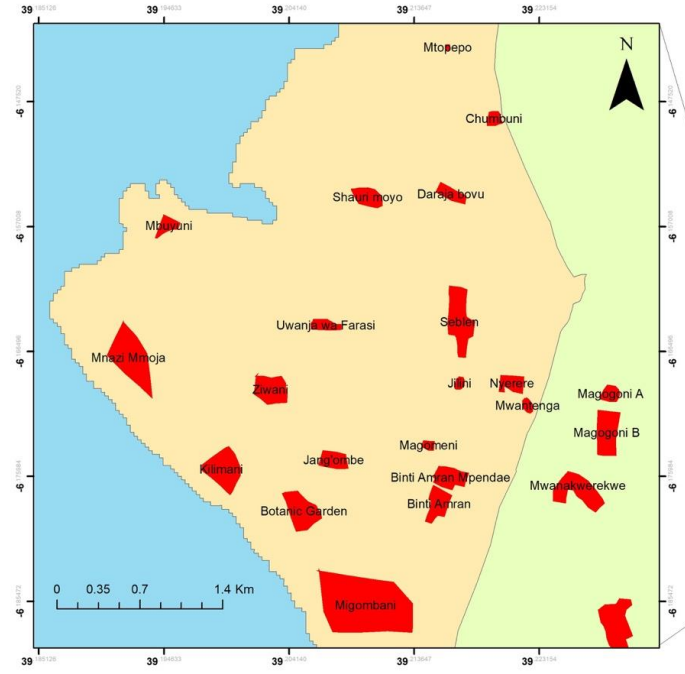

FLOOD PRONE AREA AT MJINI DISTRICT, UNGUJA ZANZIBAR
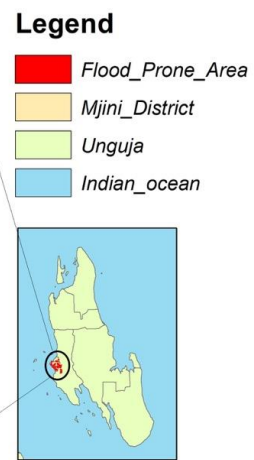

Author: Alil Badu
These priorities, as ranked by local participants, included sustainable land-management issues, such as tackling coastal erosion; addressing the widening problem of saltwater intrusion and inundation of lowland agricultural fields; reducing impacts of urban flooding; curbing rampant deforestation and land degradation; preserving Zanzibar's tourism "attractiveness" assets such as the heritage of its historic Stone Town and its constituent infrastructure; protecting coral sands and beaches, and addressing biomass energy challenges (Watkiss et al., 2012: 1).

\subsection{Development of a Zanzibar climate change adaptation strategy and action plan}

The Zanzibar climate change strategy of 2014 set up five key sectoral priorities for the Government of Zanzibar to be integrated into its poverty reduction and economic growth development strategy (Revolutionary Government of Zanzibar, 2013a: 2). These sustainable land-use planning priorities focus on natural disaster risk reduction and resilient urban settlements; climate smart agriculture; natural resources management; low-carbon tourism; sustainable forests and energy, as well as resilient coastal zone and adjacent marine ecosystems management approaches. The Zanzibar climate change action plan called for the immediate need to identify priority sites affected by climate change, and these largely related to land areas affected by salinization and flood risk (Revolutionary Government of Zanzibar, 2016: 2).

\subsection{Strategic implementation of major adaptation initiatives}

In Zanzibar, climate-smart agricultural programmes have been mobilized. Reconstruction and strengthening of dykes were prioritized. Mangrove reforestation is being carried out under multiple support from regional and global facilities. Rainwaterharvesting programmes through the construction of check dams under the Zanzibar Irrigation Masterplan 
are being implemented under a partnership with the Korea Overseas International Cooperation Agency. An expanded borehole control and monitoring programme emerged as another proposed regulatory action in addressing land-based climate issues in Zanzibar. Other popular climate adaptation initiatives included construction of seawalls and groynes at Kilimani locality in Zanzibar Town (and at Kisiwa Panza islet off Pemba); dissemination of environmental, climate education, and awareness programmes to local communities; selection of ecosystem-based management options; introduction of smart technologies; promotion of alternative livelihoods; building institutional capacity in climate financing, and enforcement of coastal setback buffer zones to slow down vulnerabilities and prolong resilience for the archipelago (UNEP \& GEF, 2015: 2).

Moreover, as Tanzania is updating its intended Nationally Determined Contributions (NDCs) to a more graduated pace within the Paris Agreement on climate change, key land-related focal areas that have been identified in the proposed NDC implementation plan for the country include adopting climate-smart land-use planning and management systems, human settlements, agriculture, water, tourism, protected areas, and waste management (United Republic of Tanzania, 2016: 1). In the Zanzibar context, these NDC measures form the bulk of the archipelago's development planning priorities that recognize the impacts of climate change on its vulnerable population.

\subsection{Challenges of climate financing and global outreach}

Despite these measures, Zanzibar's responses to climate impacts were already exacerbated by lack of institutional arrangements and planning systems, inadequate finance allocations on adaptation measures, and lack of specific economic and finance planning systems targeted at climate change. According to the
International Institute for Environment and Development, the country's capacity to absorb climate finance per year was less than US\$500,000, while adaptation demand exceeded US\$2 million each year (Vuai, 2014: 1). The 2017 natural catastrophic risk profile assessment by the World Bank's Southwest Indian Ocean Risk Assessment and Financing Initiative (World Bank, 2016a: 2) puts Zanzibar's potential catastrophic losses from natural disasters (including floods and cyclonic weather events) at US\$2.2 million each year, with an annual emergency cost of US\$500,000. The urban residential sector experiences nearly $87 \%$ of the combined losses, while the commercial sector absorbs nearly 11\% (World Bank, 2017: 1).

\subsection{Prioritizing climate-related policy interventions}

What does the existing policy context entail in addressing climate adaptation in Zanzibar? The Zanzibar Vision 2020 government plan recognized the role of the environment, biodiversity and forestry in the promotion of sustainable development, decrease in forest cover, and rapid and unplanned land-use conversion into other nonforest activities such as agriculture, urbanization, and quarrying (Revolutionary Government of Zanzibar, 2000: 1). Forest resources in the coral rag areas, agroforestry systems and mangroves have decreased significantly. The major causes are population increase and the demand for economic development, exacerbated by the fast-growing tourism industry (Kingazi, 2013). Moreover, the Zanzibar Poverty Reduction and Growth Strategy recognizes that attaining environmental sustainability and climate resilience is one of the five principal pillars towards achieving social and economic prosperity and reaching middle-income status.

The MKUZA Strategy (Revolutionary Government of Zanzibar, 2015: 2) underscores the need for a genderresponsive climate adaptation plan that targets the resilience of all socio-economic safeguards, in line with the United Nations Sustainable Development Goals. However, its implementation plan is extremely dependent on the international climate finance mechanisms and on donor support. Moreover, were Zanzibar to actually achieve middle-income status, numerous international funding opportunities for climate mitigation would disappear, since they are set aside for low-income countries.

\subsection{Integrating climate, land use and sustainability}

The last decade from 2010 to 2020 has witnessed a substantive rise in planning endeavours and environmental policy development for the islands, and notably for urban Zanzibar. Between 2013 and 2020 alone, the government of Zanzibar created the first master plan for the city in 33 years (DOURP, 2015: 1), a national spatial development strategy (Revolutionary Government of Zanzibar, 2014: 2) that included 10 focused 'local area plans' (e.g., DOURP, 2016), a new national environmental policy (2013), a new land policy (2017: 2), the new Zanzibar Environmental Management Authority (2015), and the US\$193 million World Bank-funded Zanzibar Urban Services Project (ZUSP) (World Bank, 2016b). There have been real and tangible impacts from many of these new plans and institutions. ZUSP, for example, produced almost $20 \mathrm{kms}$ of a drainage network in poorer outlying neighbourhoods that has the prospect of reducing the susceptibility of these areas to water-borne diseases such as cholera, and diseases exacerbated by standing water such as malaria. The banning of plastic bags under the new environmental policy has made the city and coastline visibly cleaner, while raising the environmental consciousness of ordinary residents.

However, implementation and enforcement mechanisms lag behind the impressive record on paper. The government's new land policy attests that climate change, rapid population 
growth, and urbanization as experienced in Zanzibar will exhaust the carrying capacity of the already over-exploited land and impose unbearable pressure on existing ecosystems and environmental services. The policy cautions that the urban areas of Zanzibar are forecast to be comprised of $60 \%$ (or 1.25 million people) of the total population projection of nearly 2.2 million by 2035 - mainly in Zanzibar Urban-West Region, and in Chake Chake and Wete towns on Pemba island (Muhajir, 2020: 64).

This climate-land nexus scenario is expected to overwhelm the carrying capacity of the fragile archipelagic environment, its settlements, and its agricultural land. This will impose further pressure on the limited government resources for managing or enhancing accessibility to affordable urban housing, sustainable infrastructure, public transport, or utility services (Revolutionary Government of Zanzibar, 2017: 2). The land policy, therefore, calls for an immediate cross-sectoral and integrated approach, or a new mechanism in achieving resilience in land-use planning through climate adaptation, disaster risk reduction, and implementation of sustainable development goals (Muhajir, 2020: 75).

\subsection{Is climate-land scenario planning the answer?}

A practical example of how the integration of land-use planning and climate adaptation can be achieved in urban settlements of Zanzibar can be referenced from The Hague Institute's pilot study in three smaller urbanized localities - Mjini Kiuyu (Pemba), Mkokotoni (Unguja), and Nungwi (Unguja) - between 2015 and 2017 (The Hague Institute, 2017: 33). The program's overall objective was to develop a Zanzibarcentric model of a participatory and community-oriented local adaptation plan of action for urbanized localities in the implementation of Zanzibar's climate strategy (The Hague Institute, 2017: 33). The three localities were selected because of their diverse climate impact challenges related to land, freshwater, rise in sea level, agriculture, livestock, and other issues. The local action plans for these urbanized localities were meant to contribute to sustainable economic development, climate change adaptation, and disaster risk reduction for these townships by developing effective institutional, sectoral and spatial governance arrangements in a participatory process.

The Pilot Study helped generate mutual trust and the development of consensus-based solutions. It also assisted policymakers in identifying relevant good practices among the persons and organizations involved in climate change issues in those localities. Over a period of two years, the formulation of the 23 recommended adaptation measures and a road map to their implementation were successfully completed (The Hague Institute, 2017: 33). The plans were effectively established while taking into consideration the priorities of these localities, including attempts to strengthen institutional capacity for planning and implementation; inter-sectoral collaboration and synergies, and community capacity for planning and implementation. However, significant challenges in both land-use planning and the decision-making hierarchy for addressing climate adaptation actions have emerged. Although the study provided the Government of Zanzibar with concrete building blocks that would support the implementation of the Zanzibar climate change strategy, its full-scale implementation has not yet been carried out and will depend on how these solutions are integrated into the current spatial development strategy.

\subsection{Managing climate vulnerabilities, natural disasters and land-use planning}

The Zanzibar National Spatial Development Strategy (NSPDS) was formulated to replace the national land-use plan of 1995, which had not been successfully implemented. The current strategy marks a departure from the traditional proactive "spatial planning" per se and instead focuses on strategic planning dialogue, in order to address key strategic measures to offset the socio-economic and environmental impacts associated with land-use planning and degradation. The Government faces the huge and seemingly insurmountable challenge of having to cope with an increasing proportion of unplanned settlements. It is now estimated that at least $60 \%$ of housing construction projects in urban areas of Zanzibar have been done without formal permit clearance (Muhajir, 2020: 65). In this scenario, where many of these structures are located within designated monsoon-season flood zones of the urban areas, the vulnerabilities to potential threats from natural disasters increase haphazardly and astronomically (Revolutionary Government of Zanzibar, 2014: 2).

Another serious challenge emanates from the fact that Zanzibar's disaster risk reduction governance framework faces both policy coordination and capacity impediments. While the disaster management policy and communication strategy recognizes the urgent need to address risks related to extreme weather events, changing sea level, and coastal pressure dynamics, the absence of practical linkages between disaster management, land-use planning, and climate adaptation safeguards has affected preventive response measures against climate impacts. As a consequence, not enough concrete cross-sectoral steps have been taken at the policy and planning level to collectively prevent or mitigate the existing fallout of the recent urban floods in Zanzibar Town (Revolutionary Government of Zanzibar, 2013b; Pardoe, Conway, Namaganda, Vincent, Dougill \& Kashaigili, 2018: 865-870; BBC, 2017).

Thompson (2020: 191) argues that the following constitute significant challenges to mainstream climate strategy across the board in Zanzibar: 
(1) insufficient funding levels towards climate adaptation that are heavily dependent on donor support; (2) a presence of little systematic mainstreaming of climate action plans at strategic or programmatic levels across the development sectors; (3) a disconnect that continues to exist between national and local government adaptation priorities, hindering the implementation of climate action plans, and (4) limited climate change knowledge and low-level institutional capacities. These prevalent challenges underscore the fundamental need for the Government to employ cross-sectoral policy and structural interventions to collectively address land-use planning, climate adaptation, and natural disaster risk reduction measures.

\subsection{Linking climate, land use and urban flooding}

The recent World Bank-financed disaster risk profile for Zanzibar focused on three perils: tropical cyclones, floods, and earthquakes (World Bank, 2016a: 1). However, there is an evidence-based agreement that flooding is by far the most significant risk in the study, causing nearly 90 of the average loss per year. A 100-year return period flood event would produce direct losses of US\$13 million and require approximately US $\$ 2.9$ million in emergency costs (World Bank, 2016a: 1). Unguja (Zanzibar) island has slightly higher absolute flood losses than Pemba island.

Recent episodes have underscored the urgent importance of enhancing the resilience of Zanzibar City against increasing episodes of extreme weather events induced by climate change. From 15 to 17 April 2005, the flooding episode caused by incessant rains directly affected 10,000 people in the urban areas and resulted in significant loss to the municipal infrastructure.

The 2005 floods along with the 2011 monsoon in Zanzibar were considered rare events (Myers, 2016: 102). However, recently, the frequency of monsoon flood events in Zanzibar has increased, with a deadly intensity. In April 2016, the rains that were induced by the remnants of a dissipated regional cyclone Fantala resulted in at least one person dead and many displaced after their houses were flooded following heavy rains. At least 300 households within the Zanzibar municipality were damaged (Juma, 2016: 1). Kombo and Faki (2019: 1) later revised the damage assessment of the Fantala episode, stating that the thermodynamic conditions of Fantala influenced heavy rainfall of greater than $170 \mathrm{~mm}$ over most stations in Zanzibar, rendering 420 people homeless, with at least 3,330 houses destroyed, and 2 fatalities.

In May 2017, the Government had to temporarily close schools, due to the onset of deadly monsoon floods, affecting over 350,000 students throughout the island. Similarly, the intense monsoon rains of 12-18 April 2018 resulted in 191 households being displaced and 225 houses damaged. As a result, the majority of flood victims sought refuge with relatives and neighbours, while 19 households did not relocate and continued to haphazardly live in their flooded houses. These intense monsoon episodes continued through 2019, when Zanzibar airport recorded $328 \mathrm{~mm}$ of rain in just three days.

\section{DISCUSSION}

\subsection{Resilience and food security}

Fundamentally, "resilience" is the persistence of healthy individuals, communities and environments to exogenous shock (Folke, 2006). The ability to make incremental social and socio-ecological adjustments increases the capacity to absorb shocks, including those linked to climate (Friend \& Moench, 2013; Tanner, Lewis, Wrathall, Bronen, Cradock-Henry, Huq, Lawless, Nawrotzki, Prasad, Rahman, Alaniz, King, McNamara, Nadiruzzaman, Henly-Shepard \& Thomalla, 2015: 23-25). Exogenous shock may impact on ecosystem functions and services, public health, and livelihood sustainability, especially in vulnerable and sensitive settings and communities (HernandezDelgado, 2015: 12-15).

Inevitably, there is a complex mix of changes in political, economic and social terms, too vast for inclusion in this article, that would be essential to a more extensive analysis of climate change impacts and other environmental compounding factors now prevalent in Zanzibar and the wider Southeast Africa (Douglass, Walz, Quintana-Morales, Marcus, Myers \& Pollini, 2019: 262-271; Pardoe et al., 2018: 869-871). Even remaining strictly within the climate change policy framework and assessment of implementation, while Zanzibar has had remarkable productivity in the formation of new plans and institutions for urban and environmental management and planning for climate change, the evidence demonstrated by the impacts of climate change specifically on urban flooding suggests that these have not been sufficient.

The net effect is that Zanzibar must be viewed as ill-prepared to confront the climate emergency that is already happening, let alone the greater climate vulnerability crises to come. The city-scale resilience of Zanzibar City is enmeshed with its outer landscape and the rural communities and resources of Unguja (Myers, 2016: 98; Muhajir, 2020: 75).

Thus, climate change impacts that influence the city's social, economic, and environmental outcomes have reverberating consequences throughout the island, and vice versa.

It is important, then, to also consider how climate change degrades and damages farmland, forests, coastlines, and the marine ecosystems that directly interface with Zanzibar City and Unguja. The coastal niches of significance are mangrove forests, seagrass beds, and fringing coral reefs, all critical for ecosystem function and sustainable livelihoods, and as carbon reservoirs. For instance, coral reefs bleached by increased sea surface temperatures reduce nearshore fish catches (and negatively impact on the livelihoods of fisher people) and 
expose coastlines to destructive wave action. Fish are an essential food protein in Zanzibar, and they also meet the needs of hotels and restaurants in the city's tourist sector.

\subsection{The role of large-scale and NGO financing in mainstreaming climate adaptation}

Large-scale donor-funded climate adaptation interventions provide a critical level of impact alleviation approach and a strategic guidance for climate resiliency in both urban and rural settings relevant to Zanzibar. But these interventions are largely top-down in orientation, and do not sufficiently integrate community participation, experiences and solutions into overall approaches, a typical challenge. Smaller NGOs in both urban and rural Zanzibar usually have the potential to be closer to the communities and, therefore, more practical in understanding and addressing community-oriented priorities in climate adaptation and sustainable livelihoods. However, these NGOs' abilities to receive, digest, adopt, communicate, mainstream, and implement plans do not necessarily mean that their desired interventions are often inculcated in the wider nationally recognized response measures.

Nonetheless, there are some positive developments or examples in this regard, for instance the collaboration between the International Institute for Environment and Development and the Zanzibar Climate Change Alliance to support climate resilient cooperative-led enterprises in the archipelago (IIED, 2018). The project emphasizes capacitybuilding, including for civil society organizations, and decentralized climate finance projects. Although two years in duration, its initiatives on deep-water seaweed farming, citrus farming (especially limes), and honey production integrated local needs and experiences with in-country financing that boosted local livelihoods and rural products for markets in Zanzibar City.

\subsection{The future of disaster risk, climate and planning for Zanzibar}

A lack of evidence-based policy guidance on loss and risk information with respect to climate-induced natural hazards will likely affect the data-driven demand for urban spatial planning. A recent study on loss and risk analysis of public finance shows a complete absence of investments in disaster loss and risk prevention or of taking contingency measures into budgetary and financial consideration (UNISDR, 2015: 32). Critical infrastructure remains fully exposed and increasingly vulnerable to climate impact. Without sufficiently protected safeguards against disaster risk or contingency financing mechanisms on critical infrastructure and settlements, the local communities will continue to bear the brunt of the impacts of climate change.

Pilot risk probabilistic assessments using Des Inventar and CAPRA tools have been demonstrated to respond to spatial and descriptive data needs for integrated land-use planning; their long-term sustainability has been put under question, due to lack of national prioritization and budgetary finance commitments (SDG Partnership Platform, 2014). Another encouraging example is the use of drones for spatial mapping to develop efficient and updated GIS data on land-use planning in Zanzibar. These interventions show the pace of progress in addressing environmentclimate-land dynamics in Zanzibar, but they fall far short of complete adoption by the relevant sectors and are not mainstreamed into development processes (ZMI, 2016).

\subsection{Can the current interventions save the vulnerable tourism economy of Zanzibar?}

The implications and consequences of the rapid physical growth of the tourism industry in Zanzibar are contentious areas of interest that require an in-depth analysis in the context of a climate-land interface. By 2018, Zanzibar had received over 520,000 international tourists, in addition to the growing tourist clientele from mainland Tanzania. This raised the islands' prospects of becoming highly competitive with the likes of Seychelles and Mauritius, both of which also face climate change impacts, in regional tourism dynamics (UNECA, 2014: 3). With the infrastructure to accommodate such a growing demand increasingly overwhelmed, the World Bank's "Green Corridor" initiative in the middle of the Zanzibar municipality is helping the Government cope with the urban spatial planning dilemma. It is injecting funds into local urban regeneration initiatives, mobility improvements, reducing congestion, and preserving historical monuments in Stone Town (World Bank, 2018: $3)$. The success of this initiative, implemented under the ZUSP project, will depend on how the climate-land interface has been effectively taken into consideration. There must be an effective establishment of dedicated financing solutions that do not in the long term rely solely on donor support. Many other environmental impacts from the rapid growth of tourism have thus far gone on without sufficient implementation of mitigation efforts (Myers, 2016: 102; Keshodkar, 2013: 193-206).

\section{CONCLUSION}

Zanzibar already has a considerable disparity between rural and urban socio-economic conditions that exacerbate climate vulnerabilities. With population growth increasing and unequal socio-economic activities widening, both climaterelated and anthropogenic drivers of land exploitation and degradation, urbanization, deforestation, poor agricultural production, and water scarcity have been proven to have a direct bearing on the policy implementation context of climate adaptation and socio-economic justice (Kingazi, 2013). The land tenure system, along with the latest spatial planning strategy, will have to recalculate the socio-economic cost of climate change. The fact that this is not yet being prioritized in the spatial planning hierarchy risks increasing social inequities 
and exacerbating already tense land disputes between communities and major industries such as tourism.

The World Bank-financed ZUSP initiative to improve access to urban services and conserve physical cultural heritage through a series of development interventions in integrated waste management, surface drainage systems, and rehabilitation of some urban and waterfront infrastructure, has significantly transformed the surface drainage and waterfront façade of the Zanzibar municipality (World Bank, 2016b). However, there are still some long-term climate-disaster implications that continue to affect the overall sustainability of the existing climate-land planning dynamics in Zanzibar. Without the practical implementation of the current national spatial development strategy that integrated environment, climate and disaster risk reduction priorities, Zanzibar will continue to bear the brunt of the increasing impacts of climate change.

Direct impacts of climate change such as seasonal displacement of local communities from floodprone urban areas will continue to affect land-use planners in the archipelago. This will also exacerbate secondary impacts on the effective implementation of policy-oriented conflict resolution mechanism vis-à-vis land disputes (Revolutionary Government of Zanzibar, 2009). Nevertheless, the existing rate of migration of a predominantly tourism-related labour force from the mainland to Zanzibar will continue to induce the haphazard growth of informal settlements in the major and peripheral urban settings of the islands (Muhajir, 2020: 75). These will, in turn, exert more physical pressure on the coastal zone and accelerate the negative exploitation of the fragile coralline environment that forms the core basis of the tourism attraction index for the country.

There is also the issue of international climate finance flow into the United Republic of Tanzania and how Zanzibar can effectively access and utilize the funds for its local integrated planning priorities in the face of climate-induced GDP losses. In this context of Tanzania, there is always a risk of structurally separating Zanzibar's climate finance needs based on its size, and not on its climate vulnerabilities as a small island developing country. Priorities for a strategic funding versus reactive funding (Watkiss, Dyszynski, Hednriksen, Mathur \& Savage, 2013: 2) compel Zanzibar to maximize its climate finance needs via the United Republic of Tanzania, given its only semi-autonomous status as part of the Union. This is extremely important, as all these policy and planning intervention measures will require sustainable pooling of resources to implement Zanzibar's development plan. Currently, these cannot be achieved without the direct involvement of the Government of the United Republic.

In order to effectively address issues of vulnerabilities affecting the socio-economic stability and climate security of the islands' 1.8 million people, the challenge of misallocation of limited land resources should be addressed by utilizing a dynamic and horizontal urban spatial development strategy approach in decisionmaking. Participatory involvement of local communities will help augment the desired development results, by enhancing their sense of ownership of land-related development plans. It is about time that the conventional allocation of land for housing, roads, tourism resorts, and settlements was revised in favour of a more efficient and climate-smart strategy that does not marginalize the economically disadvantaged. An integrated strategic, social, environmental, and climate assessment of major development infrastructure plans should be made mandatory to all socioeconomic and industrial sectors.

Despite the increase in availability of area-based planning and management tools that have been provided under various external interventions, the current dynamism of a land-use governance approach within the country will eventually affect the strategic direction of any new climate-sensitive development vision. For a small island developing state such as Zanzibar, land and population will continue to be the single most important driving forces in sustainable development planning. This will in effect directly enhance the intensity of climate dialogue into the political sensitivities of the Government (e.g., in sustainable development, climate change, disaster risk reduction, and so forth). Ultimately, the desired level of resilience can only be achieved alongside the need for optimized climate adaptation solutions that include an equitable landtenure system, and community ownership of the solutions.

This article therefore suggests the following key policy recommendations on the basis of the above observations:

i. Challenge: Fragmented approach to the human-climate change interface with insufficient planning and implementation.

ii. Recommendation: Realization of an overarching integrated development planning authority that combines the environment, climate and sustainability nexus into development, land-use planning, and human settlement paradigms. Without the reconstituted mandate of a proactive planning commission that is empowered to directly engage in climate-smart biophysical and spatial planning decisions on land use, environment and industrial sectors on the ground, the adaptation efforts may fall far short of the targeted long-term goals of sustainability.

iii. Challenge: Artificial dichotomy of land and sea and their link to human livelihood threats and resilience.

iv. Recommendation: Recognition of the urgency of a development vision that is centred around the land-sea interaction and ecological connectivity that has defined the cultural 
settings and the livelihoods of local communities. It is thus imperative that the policy drivers stress the need to re-integrate policy, planning, institutional, and implementation aspects of their socio-economic priorities around sustainable land-use planning, disaster risk, and climate adaptation interface on the islands.

v. Challenge: Underdeveloped treatment of disaster risk and collaboration for sustainable financing.

vi. Recommendation: Enhance disaster risk reduction and climate change policy openings that provide Zanzibar with longterm and sustainable financing mechanisms and opportunities based on their existing natural resource base that extends from the land into the marine domain. This includes widening the ability to access long-term climate finance resources via the Government of the United Republic of Tanzania, mainstream nature finance solutions via biodiversity-related financing mechanisms, and preservation of the ocean to sustain the land resources.

vii. Challenge: Overly specific urban and climate change planning scenario.

viii. Recommendation: Effective collaboration with other island planning regimes in the western Indian Ocean region such as those in Mauritius and Seychelles may help Zanzibar attain a comparative and transformative planning scenario that is centred around the Climate Change, Disaster Risk and Sustainable Development Goals resilience triangle.

ix. Challenge: Relatively hierarchical and static research model.

x. Recommendation: Revamp Zanzibar's research agenda for the archipelago. Embrace an evidence-based planning approach that is horizontal, data driven, dynamic, and flexible, which will better address rapid changes in Zanzibar's socio-environmental sphere.

These key interventions will depend on the level of engagement of local communities, taking into consideration their participatory strength, equity, social and environmental justice towards their land heritage.

\section{REFERENCES}

ADDANEY, M. 2019. Adaptation governance and building resilience in the face of climate change in African cities: Policy responses and emerging practices from Accra. In: Cobbinah, P.B. \& Addaney, M. (Eds). The geography of climate change adaptation in urban Africa. New York: Palgrave Macmillan, pp. 479-498. https://doi. org/10.1007/978-3-030-04873-0_17

ADDANEY, M. \& COBBINAH, P.B. 2019. Climate change, urban planning and sustainable development in Africa: The difference worth appreciating. In: Cobbinah, P.B. \& Addaney, M. (Eds). The geography of climate change adaptation in urban Africa. New York: Palgrave Macmillan, pp. 3-26. https:// doi.org/10.1007/978-3-030-04873-0_1

ALJAZEERANEWS. 2019. Roads closed as flooding hits Dar es Salaam; warnings issued as more thunderstorms threaten coastal Tanzania. [Online]. Available at: <https://www.aljazeera.com/ news/2019/05/roads-closed-floodinghits-dar-es-salam-190507083430691. html> [Accessed: 21 July 2020].

BADUI, A.A. 2020. Map produced for this article by Ali A. Badui, Zanzibar Environmental Management Authority, 23 November 2020.

BBC (BRITISH BROADCASTING CORPORATION). 2017. Zanzibar floods close schools. [Online]. Available at: <https://www.bbc.com/news/worldafrica-39881954> [Accessed: 21 July 2020].

CELLIERS, L. \& NTOMBELA, C. 2015. Urbanization, coastal development and vulnerability, and catchments. In: Paula, J. (Ed.). The regional state of the coast report. Nairobi, Kenya: UNEP \& WIOMSA, pp. 337-394. https://doi. org/10.18356/cd2f1dd6-en
DOUGLASS, K., WALZ, J., QUINTANA-MORALES, E., MARCUS, R., MYERS, G. \& POLLINI, J. 2019. Historical perspectives on humanenvironment dynamics in Southeast Africa. Conservation Biology, 33(2), pp. 260-274. https://doi.org/10.1111/ cobi.13244

DOURP (DEPARTMENT OF URBAN AND RURAL PLANNING), ZANZIBAR. 2015. ZanPlan 2015: Master plan for Zanzibar urban area. Zanzibar: Revolutionary Government of Zanzibar, pp.1-43.

\section{DOURP (DEPARTMENT OF URBAN}

AND RURAL PLANNING), ZANZIBAR. 2016. Ng'ambo local area plan. Zanzibar: Revolutionary Government of Zanzibar and African Architecture Matters, pp. 265-371.

DU TOIT, M., CILLIERS, S., DALLIMER, M., GODDARD, M., GUENAT, S. \& CORNELIUS, M. 2018. Urban green infrastructure and ecosystem services in sub-Saharan Africa. Landscape and Urban Planning, vol. 180, pp. 328-338. https://doi. org/10.1016/j.landurbplan.2018.08.016

ERNSTSON, H., \& SWYNGEDOUW, E. 2019. Politicizing the environment in the urban century. In: Ernstson, H. \& Swyngedouw, E. (Eds). Urban political ecology in the Anthropo-obscene: Interruptions and possibilities. New York: Routledge, pp. 3-21. https://doi. org/10.4324/9781315210537-1

FOLKE, C. 2006. Resilience: The emergence of a perspective for socio-ecological systems analyses. Global Environmental Change, 16(3), pp. 253-267. https://doi.org/10.1016/j. gloenvcha.2006.04.002

FRIEND, R. \& MOENCH, M. 2013. What is the purpose of urban climate resilience? Implications for addressing poverty and vulnerability. Urban Climate, vol. 6, pp. 98-113. https://doi. org/10.1016/j.uclim.2013.09.002

GÖSSLING, S. 2002. Humanenvironmental relations with tourism. Annals of Tourism Research, 29(4), pp. 539-556. https://doi.org/10.1016/ S0160-7383(01)00069-X

HERNANDEZ-DELGADO, E.A. 2015. The emerging threats of climate change on tropical coastal ecosystem services, public health, local economies and livelihood sustainability of small islands: Cumulative impacts and synergies. Marine Pollution Bulletin, 101(1), pp. 5-28. https://doi.org/10.1016/j. marpolbul.2015.09.018 
IIED (INTERNATIONAL INSTITUTE FOR ENVIRONMENTAL DEVELOPMENT). 2018. Decentralised climate finance in Tanzania, Final Report, 30-04-2018. Dar es Salaam: IIED, pp. 1-67.

JUMA, B. 2016. Tanzania - 3 dead, 100s displaced after floods in Mbeya, Zanzibar and Kilimanjaro regions. [Online]. Available at: <http://floodlist. com/africa/tanzania-floods-mbeyazanzibar-kilimanjaro> [Accessed: 24 July 2020].

KEBEDE, A. \& NICHOLLS, R. 2011. Exposure and vulnerability to climate extremes: Population and asset exposure to coastal flooding in Dar es Salaam (Tanzania): Vulnerability to climate extremes. Regional Environmental Change, 12(1), pp. 81-94. https://doi.org/10.1007/ s10113-011-0239-4

KESHODKAR, A. 2013. Tourism and social change in post-socialist Zanzibar: Struggles for identity, movement, and civilization. Lanham, Maryland: Rowman and Littlefield.

KILLIAN, B. 2008. The state and identity politics in Zanzibar: Challenges to democratic consolidation in Tanzania. African Identities, 6(2), pp. 99-125. https://doi. org/10.1080/14725840801933932

KINGAZI, S.P. 2013. Zanzibar woody biomass survey: Prepared for REDD+ readiness phase - socio-economic survey component. Dar es Salaam: Indufor Forest Intelligence \& Norwegian Embassy, pp. 1-61.

KOMBO, H.K. \& FAKI, M.M. 2019. Assessment of the impacts of tropical cyclone Fantala to the Tanzanian coastline: The case of Zanzibar. Paper presented to the 2019 Symposium of the Western Indian Ocean Marine Science Association, Zanzibar. [Online]. Available at: <https:// symposium.wiomsa.org/wp-content/ uploads/2019/06/7-548-Kai-Kombo. pdf> [Accessed: 24 July 2020].

LARSEN, K. 2005. Where humans and spirits meet: The politics of rituals and identified spirits in Zanzibar. New York: Berghahn Books.

MOLLER, L. 2010. Adaptation to climate change - preparation of an adaptation programme of action for Zanzibar. Zanzibar: Sustainable Management of Land and Environment (SMOLE-II) Project, pp. 13-40.
MUHAJIR, M. 2020. Diagnostic report for the national urban policy, Zanzibar. Zanzibar: United Nations Habitat and Revolutionary Government of Zanzibar.

MYERS, G. 1993. Reconstructing Ng'ambo: Town planning and development on the other side of Zanzibar. Unpublished PhD thesis, University of California, Los Angeles, United States of America.

MYERS, G. 2002. Local communities and the new environmental planning: A case study from Zanzibar. Area, 34(2), pp. 149-159. https://doi. org/10.1111/1475-4762.00067

\section{MYERS, G. 2016. Urban} environments in Africa: A critical analysis of environmental politics. Bristol, United Kingdom: Policy Press. https://doi.org/10.1332/ policypress/9781447322917.001.0001

MYERS, G. 2020. Rethinking urbanism: Lessons from postcolonialism and the global south. Bristol, United Kingdom: Bristol University Press. https://doi. org/10.2307/j.ctv12fw6wq

PARDOE, J., CONWAY, D., NAMAGANDA, E., VINCENT, K., DOUGILL, A. \& KASHAIGILI, J. 2018. Climate change and the water-energyfood nexus: Insights from policy and practice in Tanzania. Climate Policy, 18(7), pp. 863-877. https://doi.org/10.10 80/14693062.2017.1386082

PAULA, J. (Ed.). 2016. Regional state of the coast report - Western Indian Ocean: A summary for policy makers. Nairobi: United Nations Environment Programme, pp. 91-93.

RELIEFWEB. 2018. Tanzania Floods. [Online]. Available at: <https://reliefweb. int/disaster/fl-2018-000043-tza>

[Accessed: 24 July 2020].

SDG PARTNERSHIP PLATFORM. 2014. Disaster risk management in the islands of the Indian Ocean. Port Louis: Indian Ocean Commission. [Online]. Available at: <https:// sustainabledevelopment.un.org/ partnership/?p=7675> [Accessed: 7 July 2020].

SILVER, J. 2019. Suffocating cities: Climate change as socio-ecological violence. In: Ernstson, H. \& Swyngedouw, E. (Eds). Urban political ecology in the Anthropo-obscene: Interruptions and possibilities. New York: Routledge, pp. 129-147. https:// doi.org/10.4324/9781315210537-7
SIMON, D. \& LECK, H. 2014. Urban dynamics and the challenges of global environmental change in the south. In: Parnell, S. \& Oldfield, S. (Eds). The Routledge handbook on cities of the global south. London: Routledge, pp. 613-628.

TANNER, T., LEWIS, D., WRATHALL, D., BRONEN, R., CRADOCKHENRY, N., HUQ, S., LAWLESS, C., NAWROTZKI, R., PRASAD, V., RAHMAN, A., ALANIZ, R., KING, K., MCNAMARA, K., NADIRUZZAMAN, M., HENLY-SHEPARD, S. \& THOMALLA, F. 2015. Livelihood resilience in the face of climate change. Nature Climate Change, vol. 1, pp. 23-26. https://doi.org/10.1038/ nclimate2431

THE HAGUE INSTITUTE FOR GLOBAL JUSTICE. 2017. Governance of climate change adaptation in Zanzibar - final report. The Hague, The Netherlands: The Hague Institute for Global Justice, May 2017, pp. 33-49. [Online]. Available at: <https:// www.thehagueinstituteforglobaljustice. org/information-for-policy-makers/ policy-brief/local-climate-action-plansmjini-kiuyu-mkokotoni-and-nungwi/> [Accessed: 17 July 2020].

THOMPSON, D.D.P. 2020. Disaster risk governance in Zanzibar. In: Thompson, D.D.P. Disaster risk governance - four cases from developing countries. London: Routledge, pp. 191-212. https://doi. org/10.4324/9781315401171-9

UNECA (UNITED NATIONS ECONOMIC COMMISSION FOR AFRICA). 2014. Climate change in the African small island developing states: From vulnerability to resilience. Addis Ababa: UNECA, pp. 3-12.

UNEP (UNITED NATIONS ENVIRONMENT PROGRAM) \& GEF (GLOBAL ENVIRONMENT FACILITY). 2015. Developing core capacity to address adaptation to climate change in productive coastal zones of Tanzania: Project general information report, fiscal year 2015. Dodoma, Tanzania: Vice President's Office, United Republic of Tanzania, pp. 2-31. [Online]. Available at: <https:// projects.unep.org/docs/gef/documents/ PIRs/2017/UNEP\%20FY17\%20 APMR\%20Part\%20II\%20PIR\%20 Reports/Climate $\% 20$ Change $\% 20$ Adaptation-FY17/4141_2017_PIR_ UNEP_Tanzania.doc> [Accessed: 17 July 2020]. 
UN-HABITAT. 2014. State of African cities 2014: Re-imagining sustainable urban transitions. Nairobi, Kenya: UN-Habitat.

\section{UNISDR (UNITED NATIONS} INTERNATIONAL STRATEGY FOR DISASTER REDUCTION). 2015. Working papers on public investment planning and financing strategy for disaster risk reduction: Review of Zanzibar. Geneva: UNISDR (now UNDRR), pp. 32-69.

UNITED REPUBLIC OF TANZANIA. 2016. Intended nationally determined contributions (INDC), United Nations Framework Convention on Climate Change (UNFCCC), pp. 1-8. [Online]. Available at: <https://www4.unfccc.int/ sites/ndcstaging/PublishedDocuments/ The $\% 20$ United $\% 20$ Republic $\% 20$ of $\% 20$ Tanzania $\% 20$ First $\% 20$ NDC/ The $\% 20$ United $\% 20$ Republic $\% 20$ of $\% 20$ Tanzania $\% 20$ First $\% 20$ NDC.pdf> [Accessed: 15 July 2020].

VUAI, S.H. 2014. Zanzibar planning and financing systems for climate change initiatives. IIED Briefing. London: IIED. https://pubs.iied. org/17225IIED/, pp. 1-4.

WATKISS, P., DYSZYNSKI, J., HENDRIKSEN, G., MATHUR, V. \& SAVAGE, M. 2013. Options for climate finance mechanism: Climate fund in Tanzania - Global climate adaptation partnership. London: United Kingdom Department for International Development (UK DFID) Climate, Environment, Infrastructure and Livelihoods Professional Evidence and Applied Knowledge Services (CEIL PEAKS) Programme, pp. 2-86.

WATKISS, P., PYE, S., HENDRIKSEN, G., MACLEAN, A., BONJEAN, M., JIDDAWI, N., SHAGHUDE, Y., SHEIKH, M.A. \& KHAMIS, Z. 2012. Economics impacts of climate change in Zanzibar. London: Global Climate Partnership, UKAID, pp. 1-36 [Online]. Available at: <http://www.economicsof-cc-in-zanzibar.org/images/

Final_Summary_vs_3.pdf.> [Accessed: 21 July 2020].

WORLD BANK. 2016a. Disaster risk profile - Zanzibar. Washington, DC: World Bank Southwest Indian Ocean Risk and Finance Initiative, pp. 1-16. [Online]. Available at: <https://reliefweb. int/sites/reliefweb.int/files/resources/ zanzibar.pdf> [Accessed: 18 July 2020].
WORLD BANK. 2016b. Tanzania - Zanzibar Urban Services Project: Additional financing and restructuring. Washington, DC: World Bank, pp. 1-21 [Online]. Available at: <http:// documents.worldbank.org/curated/ en/711101468194964127/TanzaniaZanzibar-Urban-Services-Projectadditional-financing-and-restructuring > [Accessed: 18 July 2020].

WORLD BANK. 2017. Southwest Indian Ocean Risk Assessment and Financing Initiative: Summary Report and Risk Profiles. Washington, DC: World Bank, pp. 1-24. [Online]. Available at: <https://www.gfdrr.org/ en/publication/southwest-indianocean-risk-assessment-and-financinginitiative-summary-report-and-risk> [Accessed: 18 July 2020].

WORLD BANK. 2018. Boosting inclusive growth for Zanzibar: Integrated development project (P165128) project information document, integrated safeguards datasheet, concept stage. Report No. PIDISDSC23660. Prepared $4^{\text {th }}$ April 2018. Washington, DC: World Bank, pp. 3-14. [Online]. Available at: <http:// documents1.

worldbank.org/curated/ en/170331525794513472/pdf/

Concept-Project-InformationDocument-Integrated-SafeguardsData-Sheet-Boosting-Inclusive-Growthfor-Zanzibar-Integrated-DevelopmentProject-P165128.pdf > [Accessed: 17 July 2020].

YANDA, P., BRYCESON, I., MWEVURA, H. \& MUNG'ONG'O, C. (Eds). 2019. Climate change and coastal resources in Tanzania: Studies on socio-ecological systems' vulnerability, resilience and governance. New York: Springer. https://doi. org/10.1007/978-3-030-04897-6

\section{ZANZIBAR, DEPARTMENT OF} ENVIRONMENT. 2019. Unpublished report on the environmental impacts of climate change in Zanzibar. Zanzibar: Department of Environment.

\section{ZANZIBAR, REVOLUTIONARY}

GOVERNMENT OF. 2000. Vision 2020.

Zanzibar: Revolutionary Government of Zanzibar, pp. 1-44. [Online]. Available at: <https://www.

sheriasmz.go.tz/docs/dvv9M8AK3f ZANZIBAR_VISION_2020.pdf>

[Accessed: 15 July 2020].
ZANZIBAR, REVOLUTIONARY GOVERNMENT OF. 2009. The status of Zanzibar coastal resources: Towards the development of integrated coastal management strategies and action plan. Zanzibar: Department of Environment, with the support of the World Bank Marine and Coastal Environment Project, pp. 61-80.

ZANZIBAR, REVOLUTIONARY GOVERNMENT OF. 2012. The economics of climate change in Zanzibar. Zanzibar: Revolutionary Government of Zanzibar, pp. 1-36.

\section{ZANZIBAR, REVOLUTIONARY} GOVERNMENT OF. 2013a. Zanzibar climate change strategy. Zanzibar: Revolutionary Government of Zanzibar, pp. 2-12. [Online]. Available at: <http://www.paulwatkiss.co.uk/ newimagesanddocs/Zanzibar\%20 SummaryLR\%20draft\%20final.pdf> [Accessed: 21 July 2020].

\section{ZANZIBAR, REVOLUTIONARY} GOVERNMENT OF. 2013b. National operational guidelines for the Zanzibar disaster management policy. Zanzibar: Disaster Management Commission.

ZANZIBAR, REVOLUTIONARY GOVERNMENT OF. 2014. National spatial development strategy. Zanzibar: Revolutionary Government of Zanzibar, pp. 2-88.

\section{ZANZIBAR, REVOLUTIONARY} GOVERNMENT OF. 2015. Gender analysis for climate adaptation and low carbon development. Zanzibar: Revolutionary Government of Zanzibar.

\section{ZANZIBAR, REVOLUTIONARY} GOVERNMENT OF. 2016. Zanzibar climate change action plan, 2016-2021. Zanzibar: Revolutionary Government of Zanzibar, pp. 2-46.

\section{ZANZIBAR, REVOLUTIONARY} GOVERNMENT OF. 2017. Land policy. Zanzibar: Commission of Lands, pp. 2-69.

\section{ZMI (ZANZIBAR MAPPING}

INITIATIVE). 2016. Zanzibar:

Revolutionary Government of Zanzibar. [Online]. Available at: <http://www. zmi-geonode.org/> [Accessed: 19 July 2020]. 